\title{
Direct right pulmonary artery to left atrium fistula on $\mathrm{CT}$ angiography
}

\author{
Priya Singh 다, ${ }^{1}$ Surya Pratap Singh, ${ }^{2}$ Reetinder Kaur ${ }^{1}$
}

${ }^{1}$ Radiodiagnosis, King George Medical University, Lucknow, Uttar Pradesh, India ${ }^{2}$ Cardiovascular Radiology \& Endovascular Interventions, All India Institute of Medical Sciences, New Delhi, Delhi, India

\section{Correspondence to}

Dr Priya Singh;

singhpriya2861990@gmail.com

Accepted 10 December 2021

\section{DESCRIPTION}

A 14-year-old boy presented with recurrent, progressive central cyanosis and intermittent exertional dyspnoea. On examination, there was a faint systolic murmur on the right parasternal surface. His heart rate, respiratory rate and blood pressure were normal, while oxygen saturation was $84 \%$ on room air. ECG was normal, while chest radiograph showed left atrial enlargement. Transthoracic echocardiography showed an enlarged left atrium with a posterosuperior outpouching towards the right side, showing abnormal colour flow. Left ventricle volume was normal. Contrast-enhanced echocardiography revealed early filling of left atrium simultaneously during filling of right heart with normal left ventricular emptying. These findings suggested right to left shunt. CT pulmonary angiography (CTPA) revealed a dilated aneurysmal fistulous communication between the posterior wall of the right main pulmonary artery and left atrium (RPA-LA) on the right side (figures 1 and 2). There was early contrast opacification of the left atrium during the pulmonary phase of CTPA. All the pulmonary veins were normal and draining in the left atrium without any communication with the fistula. Catheter-guided closure of fistula using Amplatzer closure device was being planned for treatment. However, due to financial constraints procedure was postponed.

RPA-LA fistula is a rare congenital abnormality with less than 70 cases reported in the literature, and CT imaging appearance is further less commonly described. ${ }^{1}$ It is a direct communication between the right pulmonary artery or its branches and left atrium causing right to left shunting. ${ }^{1}$

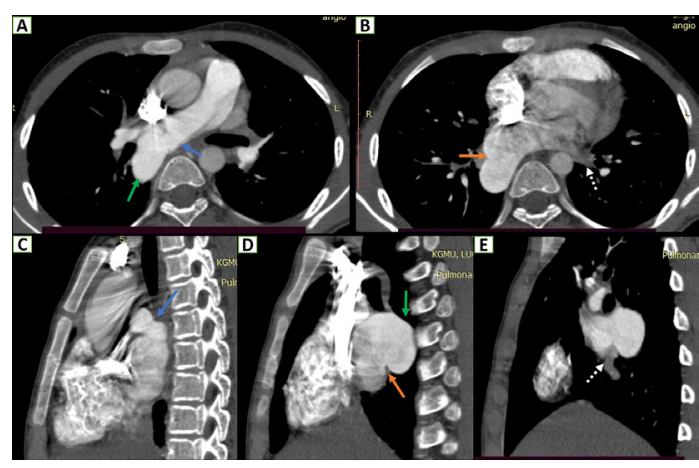

Figure $1 \mathrm{CT}$ pulmonary angiography images in axial ( $\mathrm{A}$, $B)$ and in sagittal (C, D, and E) planes showing a dilated aneurysmal fistulous (green arrows) communication between the right pulmonary artery (blue arrows) and left atrium (orange arrows) with early opacification of the left atrium. Note: normally draining non-opacified pulmonary veins (dotted white arrows).
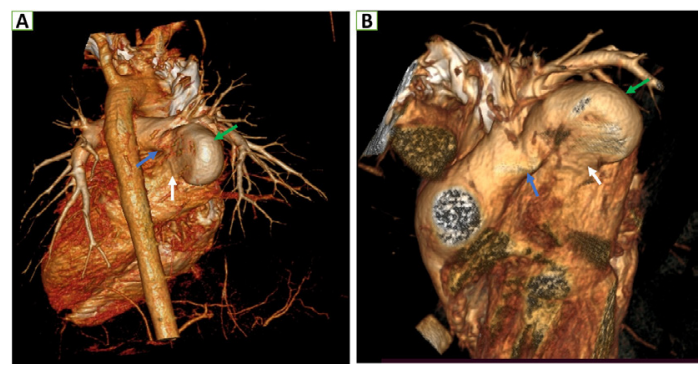

Figure 2 Volume rendered CT pulmonary angiography $(A, B)$ images showed a dilated aneurysmal fistulous (green arrows) communication between the right pulmonary artery (blue arrows) and left atrium (white arrows).

The presentation can be late depending on fistula size with central cyanosis, clubbing, exertional dyspnoea and uncommonly with complications of systemic embolism. ${ }^{12}$ Suspicion of RPA-LA fistula is usually raised on echocardiography. ${ }^{2}$ Diagnosis of RPA-LA fistula can be confirmed on CTPA. On CTPA, a fistula will be seen between the two with an early filling of the left atrium through the fistula during the pulmonary arterial phase of CTPA, when the contrast has not reached into pulmonary

\section{Patient's perspective}

I was having recurrent episodes of blue discolouration of lips and skin since long time. Recently, I am also developing dyspnoea especially on playing. Doctors after doing various tests found that there is some abnormal congenital communication in my heart. They discussed various treatment options with my parents. My parents have decided to get it done after few months after finances are arranged.

\section{Learning points}

- Direct right main pulmonary artery to left atrium fistula is a rare congenital abnormality presenting with recurrent cyanosis and exertional dyspnoea usually during adolescence.

- CT pulmonary angiography confirms the diagnosis showing early opacification of left atrium from aneurysmally dilated fistulous communication.

- Depending on the size, they can be treated surgically or by transcatheter techniques. 
veins. It is classified into four types based on communication and/or absence of pulmonary veins. ${ }^{1}$ We described a case of type 1 RPA-LA fistula and highlighted the importance of CTPA in its diagnosis. Surgical closure or catheter-guided techniques are used for the treatment of RPA-LA fistula depending on the size of fistula and feasibility. ${ }^{3}$ Catheter-guided techniques have the advantage of less procedural and postprocedural complications with faster recovery, however, requires expertise. ${ }^{3}$

Contributors Inception, preliminary writing, and image collection were done by PS. Image formatting and final revision were done by SPS, RK.

Funding The authors have not declared a specific grant for this research from any funding agency in the public, commercial or not-for-profit sectors.

Competing interests None declared.

Patient consent for publication Consent obtained from parent(s)/guardian(s).
Provenance and peer review Not commissioned; externally peer reviewed.

Case reports provide a valuable learning resource for the scientific community and can indicate areas of interest for future research. They should not be used in isolation to guide treatment choices or public health policy.

\section{ORCID iD}

Priya Singh http://orcid.org/0000-0003-0110-4242

\section{REFERENCES}

1 Chowdhury UK, Kothari SS, Airan B, et al. Right pulmonary artery to left atrium communication. Ann Thorac Surg 2005;80:365-70.

2 Zhu J, Xi E-P, Yan M, et al. Right pulmonary artery to left atrial fistula confirmed by 320-slice computerized tomography. Chin Med J 2015;128:2549-50.

3 Yang Y-K, Zheng H, Zhou X-L. Transcatheter closure or surgical repair of right pulmonary artery-left atrial fistula. Cardiol Young 2017;27:819-21.

Copyright 2021 BMJ Publishing Group. All rights reserved. For permission to reuse any of this content visit

https://www.bmj.com/company/products-services/rights-and-licensing/permissions/

BMJ Case Report Fellows may re-use this article for personal use and teaching without any further permission.

Become a Fellow of BMJ Case Reports today and you can:

- Submit as many cases as you like

- Enjoy fast sympathetic peer review and rapid publication of accepted articles

- Access all the published articles

Re-use any of the published material for personal use and teaching without further permission

Customer Service

If you have any further queries about your subscription, please contact our customer services team on +44 (0) 2071111105 or via email at support@bmj.com.

Visit casereports.bmj.com for more articles like this and to become a Fellow 